\section{At-Home Bleaching: Color Alteration, Hydrogen Peroxide Diffusion and Cytotoxicity}

Leticia Cunha Amaral Gonzaga de Almeida1', Diana Gabriela Soares², Fernanda Almeida Azevedo ${ }^{1}$, Marjorie de Oliveira Gallinari', Carlos Alberto de Souza Costa $^{2}$, Paulo Henrique dos Santos ${ }^{3}$, André Luiz Fraga Briso ${ }^{1}$

This study evaluated the color change, cytotoxicity and hydrogen peroxide (HP) diffusion caused by different home bleaching protocols: 10\% carbamide peroxide (CP) for 3 or 1.5 $\mathrm{h}, 6 \%$ hydrogen peroxide for $1.5 \mathrm{~h}$ or $45 \mathrm{~min}$. To quantify the peroxide penetration, disks of bovine teeth were placed in artificial pulp chambers (APCs) containing acetate buffer, which was collected for evaluation in a spectrophotometer. For analysis of cytotoxicity, specimens were adapted in APCs containing culture medium, which subsequently was applied on MDPC-23 odontoblast-like cells for $1 \mathrm{~h}$. Cellular metabolism was evaluated by methyl tetrazolium (MTT) assay and the color change of the specimens was analyzed using the CIE $L^{*} a{ }^{*} b{ }^{*}$ system. The data were submitted to ANOVA and Fisher test $(\alpha=5 \%)$. The treatment with $10 \%$ CP for $3 \mathrm{~h}$ was the most effective, and 6\% HP for 45 min produced the lowest color change. The groups 10\% CP for $1.5 \mathrm{~h}$ and $6 \% \mathrm{HP}$ for $45 \mathrm{~min}$ had the lowest trans-enamel dentinal HP penetration, and the 6\% HP for $1.5 \mathrm{~h}$ had the highest. None of the protocols affected cellular metabolism and morphology. In conclusion, reduced peroxide exposure time reduced the bleaching result; higher HP diffusion did not mean higher effectiveness.
'Araçatuba School of Dentistry, UNESP - Univ Estadual Paulista, Department of Restorative Dentistry, Araçatuba, SP, Brazil ${ }^{2}$ Araraquara School of Dentistry, UNESP - Univ Estadual Paulista, Department of Physiology and Pathology, Araraquara, SP, Brazil ${ }^{3}$ Araçatuba School of Dentistry, UNESP - Univ Estadual Paulista, Department of Dental Materials and Prosthodontics, Araçatuba, SP, Brazil

Correspondence: André Luiz Fraga Briso, Rua José Bonifácio, 1193, 16015-050 Araçatuba, SP, Brasil. Tel: +55-18-3636-3348. e-mail: alfbriso@foa.unesp.br

Key Words: odontoblasts, tooth bleaching, hydrogen peroxide, oxidants/toxicity.

\section{Introduction}

Bleaching with peroxides has been performed for over 100 years (1), however since the introduction of athome techniques (2), its popularity has increased, and it is currently one of the most requested procedures in the dental office. The original technique comprised nightly use of acetate trays containing 10\% carbamide peroxide (CP) based gel (2). This technique, when properly indicated and supervised by a dentist, provides highly satisfactory aesthetic results in most patients (3) and is the gold standard for comparison to other therapies (4).

Initially, bleaching was performed daily for $8 \mathrm{~h}$ overnight $(2,5)$, but it was found that the gel effectiveness decreased approximately 50\% $2 \mathrm{~h}$ after its application (6). This observation, in addition to the discomfort of the trays (6), has motivated the reduction of the time of its use, which avoids unnecessary oral exposure to the bleaching product $(6,7)$. Products containing low hydrogen peroxide (HP) concentrations (3-12\%) have also been proposed. However, while studies evaluating high concentration HP bleaching are common $(4,8,9)$, those evaluating the efficacy and safety of HP products for home use are scarce. This is troubling because HP-based gels provide more intense diffusion than the traditional $10 \%$ CP products (5), resulting in higher risks of peroxide diffusion, damage to the pulp tissue (10), and dental sensitivity $(5,9)$, which is the side effect most frequently reported by patients (9).

Thus, the present study evaluated and compared the tooth color change, HP diffusion, and cytotoxicity of homebased bleaching products containing 6\% HP and 10\% CP, applied for varying times on the dental substrate, to verify if a reduced exposure time can reduce the toxic effects without impairing the bleaching effectiveness and if $6 \%$ HP product is less toxic than 10\% CP.

The null hypotheses tested in this study were: 1 - The different bleaching protocols do not affect the color alteration. 2- The different bleaching protocols do not affect the hydrogen peroxide penetration through the tooth structure. 3 - There is no difference in the cytotoxicity of different bleaching protocols.

\section{Material and Methods Enamel/Dentin Specimens}

Enamel and dentin discs ( $5.2 \mathrm{~mm}$ diameter) were excised from the middle third of the labial face of previously selected bovine incisors. The dentin surface was polished with 400- and 600-grit aluminum oxide sandpaper (T469SF-Norton Abrasives; Saint-Gobain Ltda., Jundiai, SP, Brazil) to obtain a standardized final thickness of $3.5 \mathrm{~mm}$, with approximately $1.3 \mathrm{~mm}( \pm 0.2 \mathrm{~mm})$ of enamel and $2.2 \mathrm{~mm}$ $( \pm 0.2 \mathrm{~mm})$ of dentin. The smear layer was removed by applying $0.5 \mathrm{M}$ EDTA solution ( $\mathrm{pH}$ 7.4) on dentin surface 
for $30 \mathrm{~s}$ (11), followed by a deionized water rinse.

\section{Artificial Pulp Chamber Preparation}

Artificial pulp chambers (APCs) (12) were made of stainless steel and had 2 compartments. The upper compartment contained an opening with an $8 \mathrm{~mm}$ diameter, while the lower portion had a $6 \mathrm{~mm}$ diameter, which maintained fixation of the enamel/dentin disk. Thus, the enamel/dentin specimens were fixed in the upper compartment between 2 silicon rings (Rodimar Rolamentos Ltda.- Araraquara, SP, Brazil). Additional sealing was performed between the disc and the side wall of the APC, using wax (Wilson ${ }^{\circledR}$; Polidental, Cotia, SP, Brazil). The lower compartment had holes enabling circulation of solutions that remained in contact with the dentin surface (acetate buffer solution used for stabilization and quantification of peroxide, or the culture medium for cytotoxicity evaluation).

\section{Bleaching Treatment}

The dental specimens for color assessment $(n=15)$, HP diffusion ( $n=15)$ and for MTT assay $(n=8)$ were adapted in the APCs and the set was positioned in the wells of 24-well acrylic plates (Costar Corp. Cambridge, MA, USA) containing either acetate buffer solution or culture medium, which was in direct contact with the dentin surface. The specimens were allocated into 5 experimental groups: Group 1, no bleaching (control group); Group 2, treatment with 0.04 $\mathrm{mL}$ of Whiteness Perfect (FGM Dental Products, Joinvile, $\mathrm{SC}$, Brazil) containing 10\% CP for $3 \mathrm{~h}$ daily (minimum manufacturer's recommended time); Group 3 - received the same treatment as Group 2, but the product application time was reduced by half ( $1.5 \mathrm{~h}$ daily); Group $4,0.04 \mathrm{~mL}$ of Whiteness Class (FGM) containing 6\% HP for $1.5 \mathrm{~h}$ daily (manufacturer's recommended time); and Group 5 - the specimens were treated with the same product of Group 4, but the product remained in contact with the enamel for half the time described in the previous group, 45 min daily.

Protocols were repeated for 21 days and during the time that the samples were not bleached, they remained in contact with artificial saliva.

\section{Color Assessment}

The specimens $(n=15)$ were color assessed using an Ultraviolet Visible Spectrophotometer, Model UV -2450 (Shimadzu, Kyoto, Japan) based on a CIE L ${ }^{*} a{ }^{*} b$ * color model as established by the Commission Internacionale de I'Eclairage (CIE, International Commission on Illumination). Therefore, a black silicon individual mold was fabricated to ensure standardized readings. Three measurements were obtained for each specimen and the mean of them was calculated. Readings were performed prior to starting treatment, $24 \mathrm{~h}$ after each week of treatment, and 7 days after the treatment ended ( 28 days post-treatment).

The CIE $L^{*} a{ }^{*} b$ * system calculates the color distance between 2 pointsusing the formula: $\Delta \mathrm{E}=\left[(\Delta \mathrm{L})^{2}+(\Delta \mathrm{a})^{2}+\left(\Delta \mathrm{b}^{2}\right]^{1 / 2}\right.$. The $\Delta \mathrm{E}$ was calculated relative to the pretreatment mean value. Data were analyzed using ANOVA and Fisher test $(\alpha=5 \%)$, using StatView statistical software version 5.0.1 (SAS Institute, Cary, NC, USA).

\section{HP Diffusion}

To quantify HP diffusion, the enamel/dentin-APCs units $(n=15)$ were placed in 24-well plates containing $1 \mathrm{~mL}$ of acetate buffer solution ( $2 \mathrm{~mol} / \mathrm{M}, \mathrm{pH}$ 4.5). While the dentin was immersed in the solution, enamel was exposed to the bleaching gel. Immediately after bleaching, $100 \mu \mathrm{L}$ of the buffer solution were transferred to tubes containing $100 \mu \mathrm{L}$ of $0.5 \mathrm{mg} / \mathrm{mL}$ leucocrystal violet (Sigma Chemical Corp., St. Louis, MO, USA), $50 \mu \mathrm{L}$ of $1 \mathrm{mg} / \mathrm{mL}$ horseradish peroxidase enzyme solution (Sigma), and 2,750 mL of distilled water. This method is based on the interaction between HP and the leucocrystal violet, catalyzed by peroxidase (13); the mixture color intensity varies according to HP concentration, enabling measurement of the diffused peroxide. The optical density of the resulting blue solution was measured using a UV Visible spectrophotometer (UV-2450; Shimadzu) at a 596 $\mathrm{nm}$ wavelength. The optical density values were converted into micrograms of peroxide per milliliter of acetate buffer solution using a standard curve. HP was quantified after each bleaching session, and the data were statistically analyzed with ANOVA and Fisher test $(\alpha=5 \%)$ using StatView statistical software version 5.0.1 (SAS Institute).

\section{Cell Culture}

MDPC-23 (14) cells were seeded $\left(30,000\right.$ cells $\left./ \mathrm{cm}^{2}\right)$ into the wells of 24-well acrylic plates using plain DMEM (Sigma) supplemented with $10 \%$ fetal bovine serum (GIBCO, Grand Island, NY, USA). The plates were maintained in an incubator (Isotemp; Fisher Scientific, Pittsburgh, PA, USA) at $37{ }^{\circ} \mathrm{C}$ with $5 \% \mathrm{CO}_{2}$ for $72 \mathrm{~h}$. The disk/APC sets were sterilized with ethylene oxide and placed into each well with $1 \mathrm{~mL}$ DMEM without fetal bovine serum. The enamel surface was bleached according to the experimental groups, as described previously for 21 days. The culture medium in contact with dentin was replaced at each day. Immediately after the last bleaching day of each week, $500 \mu \mathrm{L}$ of the extract (culture medium containing the components of bleaching gel degradation that diffused through the dentin/ enamel specimens) was applied on previously cultured MDPC-23 cells for $1 \mathrm{~h}$.

\section{MTT Assay}

The cell metabolism $(n=8)$ was assessed by the methyl tetrazolium (MT) assay (15), using the cytochemical 
demonstration of succinic dehydrogenase enzyme (SDH) representing the mitochondrial respiration rate. After the cells were incubated, the extract was replaced by MTT solution ( $5 \mathrm{mg} / \mathrm{mL}$, Sigma), and the cells were incubated for additional $4 \mathrm{~h}$ at $37{ }^{\circ} \mathrm{C}$ and $5 \% \mathrm{CO}_{2}$. The formazan crystals produced by the viable cells were dissolved in acidified isopropanol solution $(0.04 \mathrm{~N} \mathrm{HCl})$ and the absorbance measured by ELISA ( $570 \mathrm{~nm}$; Tp-reader). The data were analyzed using ANOVA and Tukey test at a 5\% significance level, using StatView statistical software version 5.0.1 (SAS).

Table 1. Mean (SD) of $\Delta \mathrm{E}$ values and statistic decision for groups in different times

\begin{tabular}{lccccc}
\hline Time & Control & $10 \% \mathrm{CP} 3 \mathrm{~h}$ & $10 \% \mathrm{CP} 1.5 \mathrm{~h}$ & $6 \% \mathrm{HP} 1.5 \mathrm{~h}$ & $6 \% \mathrm{HP} 45 \mathrm{~min}$ \\
\hline $7 \mathrm{~d}$ & $1.47(0.71) \mathrm{Cab}$ & $3.86(1.01) \mathrm{Ac}$ & $3.76(0.54) \mathrm{Ad}$ & $3.55(0.30) \mathrm{Ad}$ & $2.84(0.55) \mathrm{Bd}$ \\
$14 \mathrm{~d}$ & $1.80(0.29) \mathrm{Ca}$ & $5.32(1.04) \mathrm{Ab}$ & $4.93(0.61) \mathrm{Ac}$ & $4.85(0.74) \mathrm{Ac}$ & $3.64(0.50) \mathrm{Bc}$ \\
$21 \mathrm{~d}$ & $1.52(0.31) \mathrm{Dab}$ & $6.97(0.90) \mathrm{Aa}$ & $6.31(0.74) \mathrm{Ba}$ & $6.10(0.57) \mathrm{Ba}$ & $4.52(0.54) \mathrm{Ca}$ \\
$28 \mathrm{~d}$ & $1.18(0.47) \mathrm{Db}$ & $6.75(0.90) \mathrm{Aa}$ & $5.70(0.86) \mathrm{Bb}$ & $5.46(0.76) \mathrm{Bb}$ & $3.99(0.60) \mathrm{Cb}$ \\
\hline
\end{tabular}

Different uppercase letters in columns and lowercase letters in rows indicate statistically difference.

\begin{tabular}{|c|c|c|c|c|c|}
\hline Time & Control & $10 \% \mathrm{CP} 3 \mathrm{~h}$ & $10 \%$ CP $1.5 \mathrm{~h}$ & $6 \% \mathrm{HP} 1.5 \mathrm{~h}$ & $6 \% \mathrm{HP} 45 \mathrm{~min}$ \\
\hline $7 d$ & $0.12(0.06) \mathrm{Da}$ & $0.40(0.07) \mathrm{Bb}$ & $0.26(0.07) \mathrm{Cb}$ & $0.46(0.09) \mathrm{Ab}$ & $0.26(0.06) \mathrm{Cb}$ \\
\hline $14 \mathrm{~d}$ & $0.09(0.04) \mathrm{Da}$ & $0.46(0.28) \mathrm{Ba}$ & $0.31(0.05) \mathrm{Ca}$ & $0.52(0.07) \mathrm{Aa}$ & $0.32(0.05) \mathrm{Ca}$ \\
\hline $21 \mathrm{~d}$ & $0.13(0.03) \mathrm{Ca}$ & $0.39(0.18) A \mathrm{~b}$ & $0.26(0.05) \mathrm{Bb}$ & $0.42(0.09) \mathrm{Ab}$ & $0.29(0.05) \mathrm{Bab}$ \\
\hline
\end{tabular}

Different uppercase letters in columns and lowercase letters in rows indicate statistically difference.

\section{Scanning Electron Microscopy- SEM}

Cell morphology $(n=2)$ was examined with a scanning electron microscope (Philips FEG XL 30; Oxford Instruments, Inc., Concord, MA, USA). After 60 min of cell incubation in contact with the extracts, they were aspirated, and the cells rinsed with phosphate buffer saline solution and fixed with $2.5 \%$ buffered glutaraldehyde at room temperature. After that, the cells were post-fixed with $1 \%$ osmium tetroxide, dehydrated in a series of increasing ethanol concentrations (30,50,70, 95 and 100\%), and immersed in

1,1,1,3,3,3-hexamethyldisilazane. The cover glasses with the cells on them were mounted on stubs, stored in a vacuum desiccator for $72 \mathrm{~h}$ at room temperature, and sputter-coated with a gold layer.

\section{Results}

The specimen color changed gradually and continuously beginning at the first week of bleaching treatment. The analysis performed at 28 days post-treatment (or 7 days after the end of treatment) showed that the $10 \% \mathrm{CP} / 3 \mathrm{~h}$ group had the highest $\Delta \mathrm{E}$ value of the experimental groups and showed no color rebound. The $6 \% \mathrm{HP} / 45$ min group had the lowest chromatic alteration at each time point while the $10 \%$

Table 3. Representation in percentage of the cell metabolism (means of absorbance in $\mathrm{nm}$ ) as a function of the different treatments

\begin{tabular}{ll}
\hline Group & Mean \\
\hline Control & 100.00 \\
$10 \%$ CP 3 h 7 days & 96.29 \\
$10 \%$ CP 3 h 14 days & 104.19 \\
$10 \%$ CP 3 h 21 days & 93.52 \\
$10 \%$ CP 1.5 h 7 days & 99.26 \\
$10 \%$ CP 1.5 h 14 days & 102.04 \\
$10 \%$ CP 1.5 h 21 days & 92.81 \\
$6 \%$ HP 1.5 h 7 days & 98.63 \\
$6 \%$ HP 1.5 h 14 days & 97.66 \\
$6 \%$ HP 1.5 h 21 days & 91.26 \\
$6 \%$ HP 45 min 7 days & 92.67 \\
$6 \%$ HP 45 min 14 days & 98.13 \\
$6 \%$ HP 45 min 21 days & 95.35 \\
\hline
\end{tabular}

$\mathrm{CP} / 1.5 \mathrm{~h}$ and $6 \% \mathrm{HP} / 1.5 \mathrm{~h}$ had similar results throughout the treatment (Table 1).

All bleached groups differed from the control group in HP diffusion. The $10 \% \mathrm{CP} / 3 \mathrm{~h}$ group had less HP diffusion than the 6\% HP group ( $p<0.05)$. The $10 \% \mathrm{CP} / 1.5 \mathrm{~h}$ and $6 \%$ $\mathrm{HP} / 45$ min groups had similarly lower HP penetration at each analyzed time ( $p>0.05)$. In addition, the 6\% HP/1.5 $\mathrm{h}$ had the highest HP penetration at all periods (Table 2). Cell metabolism was unaffected in all treatment groups, remaining similar to the control group ( $p>0.05$ ) (Table 3 ).

Representative images (Fig. 1) of each bleaching protocol were selected to illustrate the effects of treatments on MDPC-23 cells. In the control group a large number of cells adhered to the glass substrate was observed. These cells exhibited a wide cytoplasm covering practically the whole substrate, the same characteristics observed in treated groups.

\section{Discussion}

In this study, the first null hypothesis was rejected, 
because the color was influenced by different protocols of bleaching. The second hypothesis was rejected because the HP penetration was influenced by different bleaching protocols. The third was accepted because the different protocols had the same cytotoxic effect.

Successful bleaching treatment whitens teeth effectively without causing damage to pulp tissue. In this context, the at-home techniques provide a good color change with minimal side effects $(3,7-9)$. The present study evaluated alternative at-home protocols in order to optimize the result without compromising safety.

It is worth noting that initially, at-home bleaching technique required $8 \mathrm{~h}$ of tray use overnight for up to 6 weeks (16). However, subsequent studies demonstrated
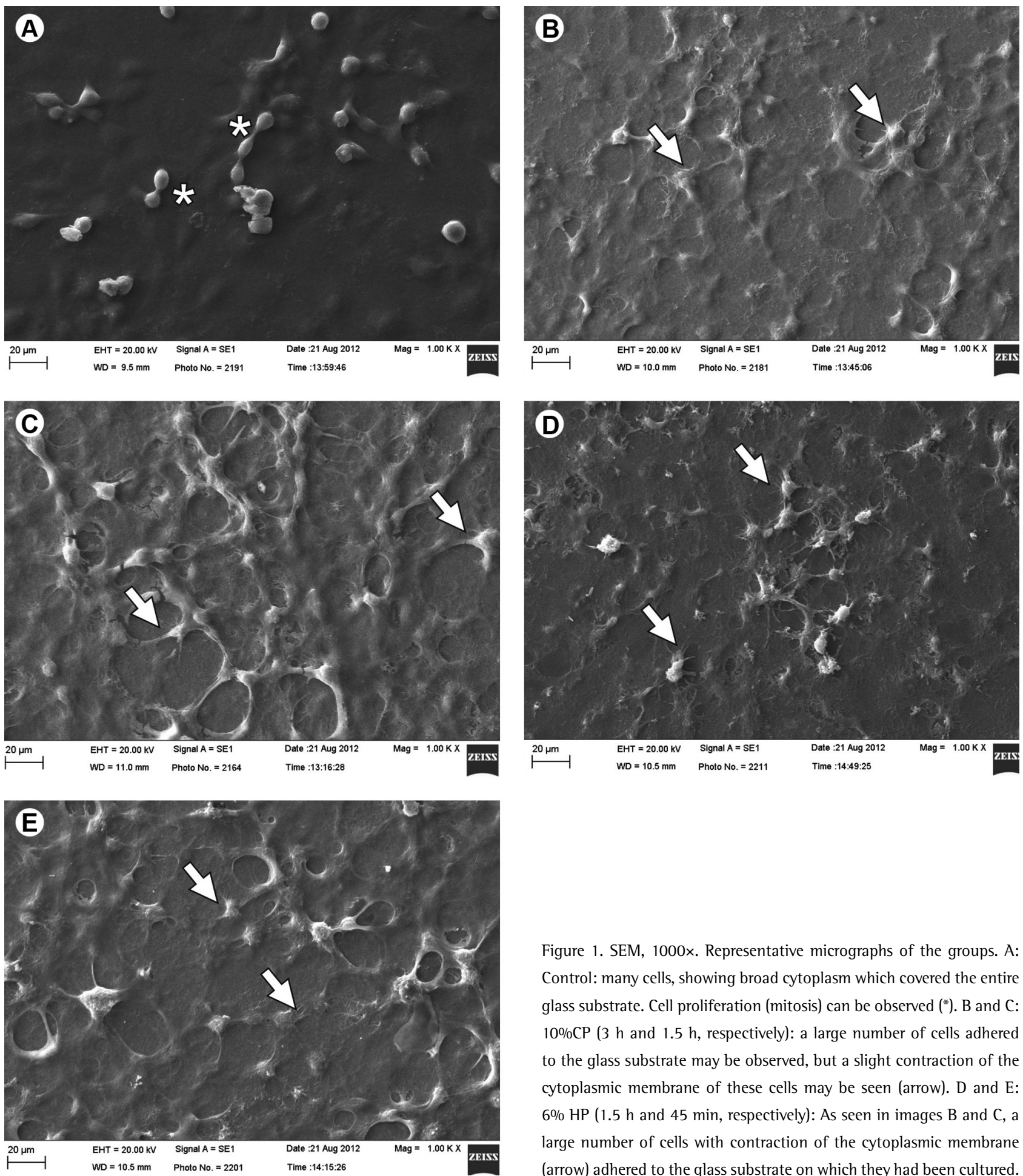

Figure 1. SEM, 1000×. Representative micrographs of the groups. A: Control: many cells, showing broad cytoplasm which covered the entire glass substrate. Cell proliferation (mitosis) can be observed $\left({ }^{*}\right)$. B and C: 10\% CP ( $3 \mathrm{~h}$ and $1.5 \mathrm{~h}$, respectively): a large number of cells adhered to the glass substrate may be observed, but a slight contraction of the cytoplasmic membrane of these cells may be seen (arrow). D and E: 6\% HP (1.5 h and $45 \mathrm{~min}$, respectively): As seen in images B and C, a large number of cells with contraction of the cytoplasmic membrane (arrow) adhered to the glass substrate on which they had been cultured. 
that after $2 \mathrm{~h}$ of product application, approximately $50 \%$ only of the active ingredient is available (6) and most treatments may be completed within 3 weeks (8). Furthermore, extended tray use causes patient discomfort and drives some patients to opt for the in-office technique. In addition, dehydration during bleaching is exacerbated in long periods of tray use, contributing to the development of sensitivity (17). More concentrated bleaching products $(7,9)$, as well as longer treatment duration (7), increase tooth sensitivity, which motivated the present investigation.

In the present study, the 10\% CP protocol duration followed the manufacturer's guidelines, which recommends at least $3 \mathrm{~h}$ of daily application. The alternative $1.5 \mathrm{~h}$ duration initially showed similar results to the standard therapy $(10 \% \mathrm{CP} / 3 \mathrm{~h})$, but the long-term effectiveness was lower at 21 and 28 days, evidenced by the significant color rebound. Nonetheless, the $\Delta \mathrm{E}$ difference was close to 1 , which is clinically irrelevant (18). In addition, $10 \%$ $\mathrm{CP}$ applied for $8 \mathrm{~h}$ lasting 16 days produced an identical bleaching effect as a 1-h treatment for 18 days, and patients using the product for $8 \mathrm{~h}$ reported more frequent sensitivity with increased intensity (7), suggesting that a reduced treatment duration could be advantageous.

The $6 \% \mathrm{HP} / 1.5 \mathrm{~h}$ protocol also followed the manufacturer's guidelines. During the first two weeks of treatment, the color change was similar to that in the 10\% CP group. However, this protocol was less effective after 21 days of bleaching and significant color rebound was observed after treatment conclusion. Further, it is notable that the 45-min application time produced the least color change for the $6 \% \mathrm{HP}$ product at all analyzed times, representing the least effective studied treatment.

Under equivalent durations ( $1.5 \mathrm{~h}$ ), the $10 \% \mathrm{CP}$ and $6 \%$ HP groups were equally effective, although the peroxide was available in higher amount and in an immediate way in the 6\% HP group. Other studies found similar effectiveness between products of different concentrations, in the at-home technique with CP (19) and in the in-office technique with $35 \%-38 \%$ HP products $(19,20)$. Hanning et al. evaluated $10 \% \mathrm{CP}$ and $6 \% \mathrm{HP}$ bleaching products and found similar efficacies (17). These results question the need to increase the active ingredient concentration to improve the treatment outcome, because the higher concentration does not necessarily yield a better result.

Treatment with $6 \% \mathrm{HP} / 1.5 \mathrm{~h}$ resulted in the highest penetration values, followed by $10 \% \mathrm{CP} / 3 \mathrm{~h}$. The $10 \%$ $\mathrm{CP} / 1.5 \mathrm{~h}$ and $6 \% \mathrm{HP} / 45$ min groups were similar and had lower penetration. The products based on HP provided a quicker diffusion through the tooth structure, because it is the active component; $\mathrm{CP}$-based products still need to dissociate, releasing only $3.3 \%$ of HP (10) and thus, a longer contact time between the product and dental tissue is required. $\mathrm{CP}$ has lower penetration into the pulp chamber than the HP at equivalent peroxide concentrations (10).

The in vivo conditions were approximated for cytotoxicity evaluations using MDPC-23 cells in addition to APCs. This cell line was established by Hanks et al. in 1998 (14) and has been widely used $(10,12,20)$. The immortalized MDPC-23 cell line, isolated from mouse molar dental papilla (Mouse Dental Papillae Cells), exhibits morphological and functional characteristics similar to those of odontoblastic cells, but with little ability to induce the dentin formation (21). These cells are the most appropriate in vitro option for evaluating the adverse effects of dental materials because the odontoblast is the first pulp cell affected by products diffusing through dental tissue (22).The differences in HP penetration between the groups were not reflected in treatment cytotoxicity, evidenced by the similar cellular metabolic rate compared to the control group. Furthermore, there were no significant changes in cell morphology. In microscopic images many cells may be seen, showing a broad cytoplasm which covered the entire glass coverslip.

In a study using similar methodology, two bleaching gels, $10 \%$ and $16 \% \mathrm{CP}$, were applied for $8 \mathrm{~h}$ daily; the authors did not observe any reduction in cellular metabolism associated with the 10\% CP gel, however, they observed a decrease in the groups treated with $16 \% \mathrm{CP}(12)$. It is worth noting that the $16 \% \mathrm{CP}$ produces an approximately 5.3\% HP concentration, which is lower than in the product evaluated in the present study and did not affect cellular metabolism. This discrepancy may reflect the reduced exposure time to the aggressive agents in the current study. The $6 \% \mathrm{HP}$ was applied to the enamel for $1.5 \mathrm{~h}$ or $45 \mathrm{~min}$, while in the cited study, the $16 \%$ CP was applied on the dental tissue for $8 \mathrm{~h}$ daily.

The final extract that was applied onto the cell cultures represents only a single product application to the tooth surface. Thus, while the color change reflects the overall treatment efficacy, the observed cytotoxic effects reflect a single day of treatment. This may have mitigated any adverse effects on the cells, but in vivo, factors such as intra-pulpal pressure, cytoplasmic processes in the dentinal tubules (23), antioxidant enzymes and other pulp defense mechanisms (24) may reduce peroxide diffusion and attenuate the intensity of adverse effects. Some in vivo studies on human premolars following 10\% CP application also report no serious pulp injuries (25) and the tissue reactions, if present, are reversible once the treatment is stopped (25).

Based on the results of this study it can be concluded that: reducing the product exposure time decreased the efficacy of 10\% CP and 6\% HP bleaching treatments; all protocols were effective, but treatment with 10\% CP for 3 hours/day was the best protocol. Higher HP diffusion did 
not mean higher effectiveness. The protocols evaluated were not cytotoxic to odontoblast-like cells.

\section{Resumo}

Este estudo avaliou a alteração de cor, a citotoxicidade e a difusão de peroxido de hidrogênio ocorridos em diferentes protocolos clareadores caseiros: peróxido de carbamida (PC) $10 \%$ por 3 ou $1,5 \mathrm{~h}$; peróxido de hidrogênio (PH) $6 \%$ por 1,5 h ou 45 min. Para a quantificação da penetração do peróxido, discos de dentes bovinos foram posicionados em câmaras pulpares artificiais (CPAs) contendo solução tampão de acetato, que foi coletada para avaliação em espectrofotômetro. Para análise da citotoxicidade, os espécimes foram adaptados nas CPAs contendo meio de cultura, que posteriormente foi aplicado sobre células odontoblastóides MDPC-23 por $1 \mathrm{~h}$. 0 metabolismo celular foi avaliado pelo teste MTT e a alteração de cor dos espécimes foi analisada pelo sistema CIE L*a*b*. Os dados foram submetidos a ANOVA e teste de Fisher $(\alpha=5)$. 0 tratamento com PC10\% por 3 horas foi o mais efetivo, enquanto que o tratamento com $\mathrm{PH}$ 6\% por 45 min produziu a menor alteração cromática. Os grupos PC $10 \%$ por 1,5 h e PH $6 \%$ por 45 min causaram a menor penetração trans-amelodentinária do peróxido, e $\mathrm{PH} 6 \%$ por 1,5 h, a maior difusão. Nenhum tratamento alterou o metabolismo celular. A redução do tempo de exposição aos peróxidos comprometeu o resultado clareador; maior penetração de peroxido não significa maior efetividade clareadora.

\section{Acknowledgements}

The authors acknowledge the Fundação de Amparo à Pesquisa do Estado de São Paulo/FAPESP (Grants \#2010/10378-2 and \#2010/17637-3) and the Fundação para o Desenvolvimento da UNESP/FUNDUNESP (01136/10DFP) for their financial support.

\section{References}

1. Prinz, H. Recent improvements in tooth bleaching: a clinical syllabus. The Dental Cosmos 1924;66:558-560.

2. Haywood VB, Heymann HO. Nightguard vital bleaching. Quint Int 1989;20:173-176.

3. Alonso de la Peña $\mathrm{V}$, López Ratón M. Randomized clinical trial on the efficacy and safety of four professional at-home tooth whitening gels. Oper Dent 2014;39:136-143.

4. Buchalla W, Attin T. External bleaching therapy with activation by heat, light or laser - a systematic review. Dent Mater 2007;23:586-596.

5. Haywood VB. Bleaching of vital teeth: Current concepts and research. Quint Int 1997;28:424-425.

6. Matis BA, Gaiao U, Blackman D, Schultz FA, Eckert GJ. In vivo degradation of bleaching gel used in whitening teeth. J Am Dent Assoc 1999;130:227-235.

7. Cardoso PC, Reis A, Loguercio A, Vieira LC, Baratieri LN. Clinical effectiveness and tooth sensitivity associated with different bleaching times for a 10 percent carbamide peroxide gel. J Am Dent Assoc 2010;141:1213-1220.

8. Almeida LC, Riehl H, Santos PH, Sundfeld ML, Briso AL. Clinical evaluation of the effectiveness of different bleaching therapies in vital teeth. Int J Periodontics Restorative Dent 2012;32:303-309.
9. Almeida LC, Costa CA, Riehl H, Dos Santos PH, Sundfeld RH, Briso AL. Occurrence of sensitivity during at-home and in-office tooth bleaching therapies with or without use of light sources. Acta Odontol Latinoam 2012;25:3-8

10. Cooper JS, Bokmeyer TJ, Bowles WH. Penetration of the pulp chamber by carbamide peroxide bleaching agents. J Endod 1992;8:315-317.

11. Jacques $P$, Hebling J. Effect of dentin conditioners on the microtensile bond strength of a conventional and a self-etching primer adhesive system. Dent Mater 2005;2:103-109.

12. Soares DG, Ribeiro AP, Sacono NT, Coldebella CR, Hebling J, Costa CA. Transenamel and transdentinal cytotoxicity of carbamide peroxide bleaching gels on odontoblast-like MDPC-23 cells. Int Endod J 2011;44:116-125.

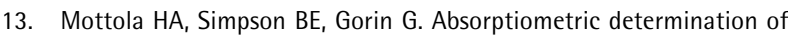
hydrogen peroxide in submicrogram amounts with leuco crystal violet and peroxidase as catalyst. Anal Chem 1970;42:410-411.

14. Hanks CT, Sun ZL, Fang DN, Edwards CA, Wataha JC, Ritchie HH, et al.. Cloned 3T6 cell line from CD-1 mouse fetal molar dental papillae. Connect Tissue Res 1998;37:233-249.

15. Mosmann T. Rapid colorimetric assay for cellular growth and survival: application to proliferation and cytotoxicity assays. J Immunol Methods 1983;65:55-63.

16. Leonard RH Jr, Haywood VB, Phillips C. Risk factors for developing tooth sensitivity and gingival irritation associated with nightguard vital bleaching. Quint Int 1997;28:527-534.

17. Hannig C, Lindner D, Attin T. Efficacy and tolerability of two home bleaching systems having different peroxide delivery. Clin Oral Investig 2007;11:321-329.

18. Stober T, Gilde H, Lenz P. Color stability of highly filled composite resin materials for facings. Dent Mater 2001;17:87-94.

19. Basting R, Amaral F, França F, Flório F. Clinical comparative study of the effectiveness of and tooth sensitivity to $10 \%$ and $20 \%$ carbamide peroxide home-use and 35\% and 38\% hydrogen peroxide in-office bleaching materials containing desensitizing agents. Oper Dent 2012;37:464-473.

20. Almeida LC, Soares DG, Gallinari MO, Souza Costa CA, Santos $\mathrm{PH}$, Briso AL. Color alteration, hydrogen peroxide diffusion, and cytotoxicity caused by in-office bleaching protocols. Clin Oral Investig 2015;19:673-680.

21. Rodriguez AP, Tsujigiwa $H$, Gunduz $M$, Cengiz B, Nagai N, Tamamura $\mathrm{R}$, et al. Influence of the microenvironment on gene and protein expression of odontogenic-like and osteogenic-like cells. Biocell 2009;33:39-47.

22. Goldberg M, Smith AJ. Cells and extracellular matrices of dentin and pulp: a biological basis for repair and tissue engineering. Crit Rev Oral Biol Med 2004;15:13-27.

23. Vongsavan $\mathrm{N}$, Matthews $\mathrm{B}$. The permeability of cat dentine in vivo and in vitro. Arch Oral Biol 1991;36:641-646.

24. Esposito P, Varvara G, Murmura G, Terlizzi A, Caputi S. Ability of healthy and inflamed human dental pulp to reduce hydrogen peroxide. Eur J Oral Sci 2003;111:454-456.

25. Fugaro OJ, Fugaro JO, Matis B, Gregory RL, Cochran MA, Mjör I. The dental pulp: inflammatory markers and vital bleaching. Am J Dent 2005;18:229-232. 